\title{
THE EFFECT OF BACKPACK LOAD ON MOTION COORDINATION OF SCHOOLCHILDREN
}

\author{
Nan ZHOU ${ }^{1,2}$, Wuyong $\mathrm{CHEN}^{1 *}$, Jin $\mathrm{ZHOU}^{1}$, Luming YANG ${ }^{1}$ \\ ${ }^{1}$ National Engineering Laboratory for Clean Technology of Leather Manufacture, Sichuan University, Chengdu, 610065, China \\ ${ }^{2}$ Guangzhou Shiling Leather\& leather products investigation center, No.6 Yangguang Road Shiling Town, Huadu district, \\ Guangzhou city, Guangdong province, 510850, China
}

Received: $12.07 .2018 \quad$ Accepted: 25.10.2018

https://doi.org/10.24264/Ifj.18.4.3

THE EFFECT OF BACKPACK LOAD ON MOTION COORDINATION OF SCHOOLCHILDREN

ABSTRACT. The aim of this study was to explore the influence of the load of a backpack on the coordination of motion of healthy children aged 7 to 12.100 healthy schoolchildren were recruited and they were quantified with the normal BMI, no foot deformities or injuries, no abnormal gait patterns. Coda Motion System was used to record the angle of walking with backpack loads of $0 \%, 5 \%, 10 \%, 15 \%, 20 \%$ and $25 \%$ of their body weight (BW) randomly. Vector angles between angle of head, body, knee and ankle were first calculated and then the phase angle (PA) and continuous relative phase (CRP) including their standard deviations (SD) were figured out. Distinctions within six load condition were evaluated by covariance univariance with significance level of 0.05 and a confidence interval of $95 \%$. Our results show that significant effect loading on the CRP of head and body was found $(p=0.005<0.01)$, where $0 \% B W(p=0.002<0.05), 5 \% B W(p=0.001<0.05)$ and $10 \% B W(p=0.008<0.05)$ were recorded with smaller CRP values than those of $20 \% B W$. However, no significant distinctions were found between $20 \% \mathrm{BW}$ and $25 \% \mathrm{BW}$. Although significant differences were not found for all PA variables, their decreased simultaneously with the weight of backpack increasing, particularly in the body and ankle. Overall, coordination in motion of schoolchildren was partially influenced by an increasing load of the backpack, as significant body tilt was performed by the children to overcome the backwards drag, while other body parts were not affected.

KEY WORDS: backpack loading, continuous relative phase, phase angle, coordination of motion

INFLUENTA GREUTĂTII RUCSACULUI ASUPRA COORDONĂRII MIŞCĂRII LA ŞCOLARI

REZUMAT. Scopul acestui studiu a fost de a explora influenţa greutăţii rucsacului asupra coordonării mişcării la copii sănătoşi cu vârste cuprinse între 7 şi 12 ani. Au fost recrutaţi 100 de elevi sănătoşi cu IMC normal, fără deformări sau leziuni la nivelul picioarelor, fără mers anormal. S-a utilizat sistemul Coda Motion pentru a înregistra unghiul de mers la o greutate a rucsacului de $0 \%, 5 \%, 10 \%, 15 \%, 20 \%$ şi $25 \%$ din greutatea corporală (BW) în mod aleatoriu. Au fost calculate mai întâi unghiuri vectoriale între unghiurile capului, corpului, genunchiului şi gleznei şi apoi s-au calculat unghiul de fază (PA) şi faza relativă continuă (CRP), inclusiv abaterile standard (SD) ale acestora. Diferenţele dintre cele şase condiții de încărcare au fost evaluate prin analiza univariată şi determinarea covarianţei cu un nivel de semnificaţie de 0,05 şi un interval de încredere de $95 \%$. Rezultatele noastre arată că s-a observat o încărcare semnificativă a CRP la nivelul capului şi corpului $(p=0,005<0,01)$, unde s-au înregistrat 0\%BW ( $p=0,002<0,05), 5 \% B W(p=0.001<0.05)$ şi 10\%BW ( $p=0.008<0.05)$ cu valori CRP mai mici decât cele obţinute în cazul $20 \%$ BW. Cu toate acestea, nu s-au constatat diferenţe semnificative între $20 \%$ BW şi 25\%BW. Deşi nu s-au găsit diferenţe semnificative între variabilele PA, acestea au scăzut simultan cu creşterea greutăţii rucsacului, în special la nivelul corpului şi gleznei. În ansamblu, coordonarea mişcării elevilor a fost parţial influenţată de greutatea crescândă a rucsacului, pe măsură ce copiii şi-au înclinat semnificativ corpul pentru a nu fi tras înapoi, în timp ce alte părţi ale corpului nu au fost afectate.

CUVINTE CHEIE: încărcarea rucsacului, faza relativă continuă, unghiul de fază, coordonarea mişcării

\section{L'EFFET DU POIDS DU SAC À DOS SUR LA COORDINATION DU MOUVEMENT DES ÉCOLIERS}

RÉSUMÉ. Le but de cette étude était d'explorer l'influence du poids du sac à dos sur la coordination des mouvements chez les enfants en bonne santé âgés de 7 à 12 ans. On a recruté 100 étudiants en bonne santé avec un IMC normal, sans déformations ni lésions des pieds sans marcher anormalement. Le système Coda Motion a été utilisé pour enregistrer l'angle de marche à $0 \%, 5 \%, 10 \%, 15 \%, 20 \%$ et $25 \%$ du poids corporel de manière aléatoire. Les angles de vecteur ont d'abord été calculés entre les angles de la tête, du corps, du genou et de la cheville, puis l'angle de phase (PA) et la phase relative continue (CRP), y compris leurs écarts-types (SD), ont été calculés. Les différences entre les six conditions de poids ont été évaluées par analyse univariée et détermination de la covariance avec un niveau de signification de 0,05 et un intervalle de confiance de $95 \%$. Nos résultats montrent qu'une charge de CRP significative dans la tête et le corps a été observée $(p=0,005<0,01)$, où on a enregistré $0 \%$ de poids corporel $(p=0,002<0,05), 5 \%$ de poids corporel $(p=0,001<0,05)$ et $10 \%$ de poids corporel $(p=0,008<0,05)$ avec des valeurs de CRP inférieures à celles obtenues pour $20 \%$ de poids corporel. Cependant, il n'y avait pas de différence significative entre $20 \%$ de poids corporel et $25 \%$ de poids corporel. Bien qu'il n'y ait pas eu de différences significatives entre les variables $\mathrm{PA}$, elles ont diminué simultanément avec l'augmentation du poids du sac à dos, en particulier du corps et de la cheville. Dans l'ensemble, la coordination du mouvement des élèves a été en partie influencée par l'augmentation du poids du sac à dos, car les enfants se penchaient de manière significative pour éviter d'être tirés vers l'arrière, alors que d'autres parties du corps n'étaient pas affectées.

MOTS CLÉS : poids du sac à dos, phase relative continue, angle de phase, coordination du mouvement

\footnotetext{
* Correspondence to: Wuyong CHEN, National Engineering Laboratory for Clean Technology of Leather Manufacture, Sichuan University, Chengdu, 610065, China, tel.: 86-28-85405237; fax: 86-28-85405237, email address: wuyong.chen@163.com
} 


\section{INTRODUCTION}

Backpack load is an important issue for the health of primary students. Trevelyan and Legg stated overloading of backpacks may cause several problems [1], like pain in the spine, shoulders, and back, etc. Consequently, problems with loading will directly or indirectly affect the growth and development of students. Singh et al. assessed 17 pupils walking on a treadmill under different weights of backpacks and suggested that with an increasing weight of the backpack [2], the body gradually leaned forward, and an increase of weight would lead to a change in body posture. Pau et al. reported that with an increasing of weight of the backpack [3], the longitudinal track of the center of pressure (COP) became longer and moved forward, and the lateral displacement of the COP became smaller. These increased discomfort and structural damage to the feet. Thus, the load has been demonstrated to change the posture of walking; but how it affects coordination has unfortunately seldom been studied.

Clark and Phillips stated walking continues to develop as the higher cortical and subcortical centers mature and gain control of the spinal level CPGs [4]. The task of walking is more difficult considering that such coordination is composed both within one leg and also between both legs. They also found that toddlers must not only be able to coordinate their two legs in order to attain upright stability and forward mobility, but also develop coordination between the joints of the knee and ankle for each individual leg [5]. Hence, by quantifying intra-limb coordination in walking, we could study the maturation of the neuro-musculo-skeletal system. Clark and Truly first quantified the motion of lower limbs and introduced a variable relative phase representing how these two (thigh and shank) limit cycle attractors are coupled [6]. After Clark, Miller et al. normalized the angle and velocity into timeless parameters and suggested that the continuous relative phase (CRP) was more suitable to quantify the coordination of motion [7]. Chiu et al. contrasted differences of coordination between young and elderly adults in walking at various speeds [8], and Continuous Relative Phase was used to study the joint coordination. Ryan Chang used Continuous Relative Phase for quantitative analysis of the coordination between the back foot and the front foot while walking [9].

Therefore, the aim of this research is to explore the influence of the load of a backpack on the coordination of motion of healthy children aged 7 to 12 . Since the load would affect the gait in the stance phase, one hypothesis was proposed that with an increasing load, coordination in the stance phase would be influenced.

\section{EXPERIMENTAL}

\section{Methods}

\section{Subjects}

In total, 100 healthy schoolchildren, ages 7 to 12 , were recruited in this study. The mean age of subjects is $9.6 \pm 1.4$ years, the mean weight is $28.4 \pm 6.0 \mathrm{Kg}$ and the mean height is $134.5 \pm 8.8 \mathrm{~cm}$. Criteria for inclusion are shown below: (1) a body mass index (BMI) consistent with the BMI standard for normal Chinese children according to Force's study; (2) no foot deformities or injuries; (3) no abnormal gait patterns, such as a crouching gait or equinus. All the measures were done after the details of this study were introduced to children's parents and their formal approvals were obtained. Moreover, all the measurements and procedures were in accordance with principles of Helsinki Declaration.

\section{Motion Capture of Children's Lower Limbs}

The Coda Motion System (Coda Motion CX1, Charnwood Dynamics Ltd., United Kingdom) was used in this study to obtain the temporalspatial parameters of children's lower limbs in normal walking. All the key points of subjects including the ear, shoulder, trochanter, knee, lateral malleolus and the fifth toe, which were marked in turn (Figure 1). The vector angle $(\theta)$ and velocity $(\omega)$ of $\angle D 1 D E, \angle O 1 O D, \angle O A B$, $\angle A B C$ in the sagittal plane were calculated. $\angle$ D1DE describes the motion of the head; $\angle O 1 O D$ describes the relative motion of the body; $\angle O A B$ and $\angle A B C$ indicate the posture of knee and ankle. Test instrument area was shown in Figure 2. 


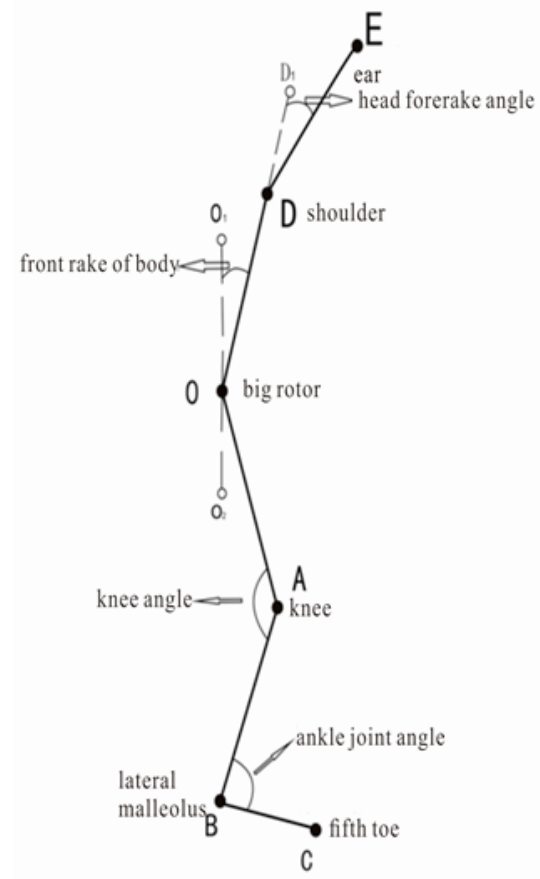

Figure 1. Graph of Key Points of Codamotion

All subjects were asked to change into tight clothing when they arrived; and then markers were set by a researcher. A three to five minute warm-up was provided for their familiarization. Afterwards, subjects walked at their own selected speed on the 6 meters track while the data recording was on (Figure $3 a$ ). All subjects were guided walking with backpack loads of $0 \%, 5 \%, 10 \%, 15 \%$ and $25 \%$ of their body weight (BW) randomly. Three successful measures for CODA test were required. The backpack used in the study was provided by Guangzhou Nuohu Company (Figure 3b).

\section{Data Processing}

Mathematical models of a continuous relative phase (CRP) were utilized (EQ 1-4) for coordination analysis. The calculation procedure is shown below: $\theta$ (Degrees) and $\omega(\mathrm{arc} / \mathrm{s})$ were first normalized into and (EQ 1 and EQ 2); and then the point phase angle (PA) was determined according to EQ 3; finally, the CRP (degrees) of body-knee and knee-ankle was resolved (EQ 4). In-phase indications were within the range of 0 to 30 degrees; while those of anti-phase were 150 to 180 degrees; other angles were classified as out-phase.

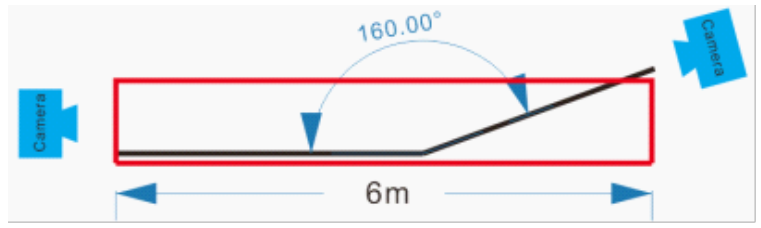

Figure 2. Graph of test instrument area
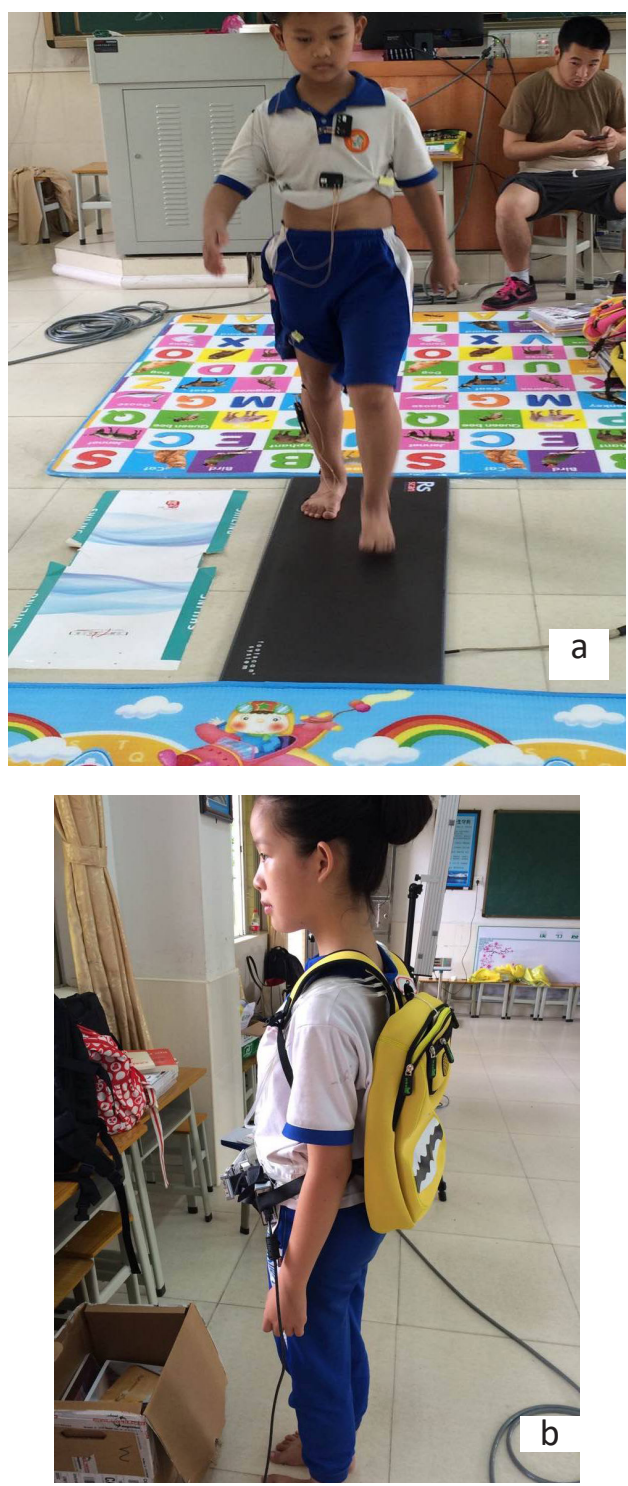

Figure 3. The backpack used in the study

$$
\begin{aligned}
& \bar{\theta}=2\left[\frac{\theta-\min (\theta)}{\max (\theta)-\min (\theta)}\right]-1 \\
& \bar{\omega}=\left[\frac{\omega}{\max (|\omega|)}\right] \quad \text { (EQ 2) } \\
& \varphi(i)=\tan ^{-1}\left[\frac{\bar{\omega}(i)}{\bar{\theta}(i)}\right], \quad i=1,2, \ldots, n \\
& \theta_{C R P}(i)=\left|\varphi_{1}(i)-\varphi_{2}(i)\right|
\end{aligned}
$$




\section{Statistical Analysis}

All the time series data was first filtered by a $6 \mathrm{~Hz}$ cut off to reduce the influence of other factors on experimental results and then the time period of a complete gait cycle was selected; further a quintic spline procedure was used to create a 100-point time-normalized gait cycle (GC). Intra-subject data was first averaged and then inter-subject data. One sample K-S model was used to test for a normal distribution and all data was found to be following a normal distribution. Variables of PA and CRP were chosen for further analysis, so the relationship between the angle $(\theta)$ and its velocity $(\omega)$ was first determined; then their consistencies were quantified in terms of standard deviations (SD). Distinctions within six load condition were evaluated by univariance with covariance of body weight. All the statistical models were executed under SPSS 16 with a significance level of 0.05 and a confidence interval of $95 \%$.

\section{RESULTS}

The Relationship between the Angle of Joints and Velocity
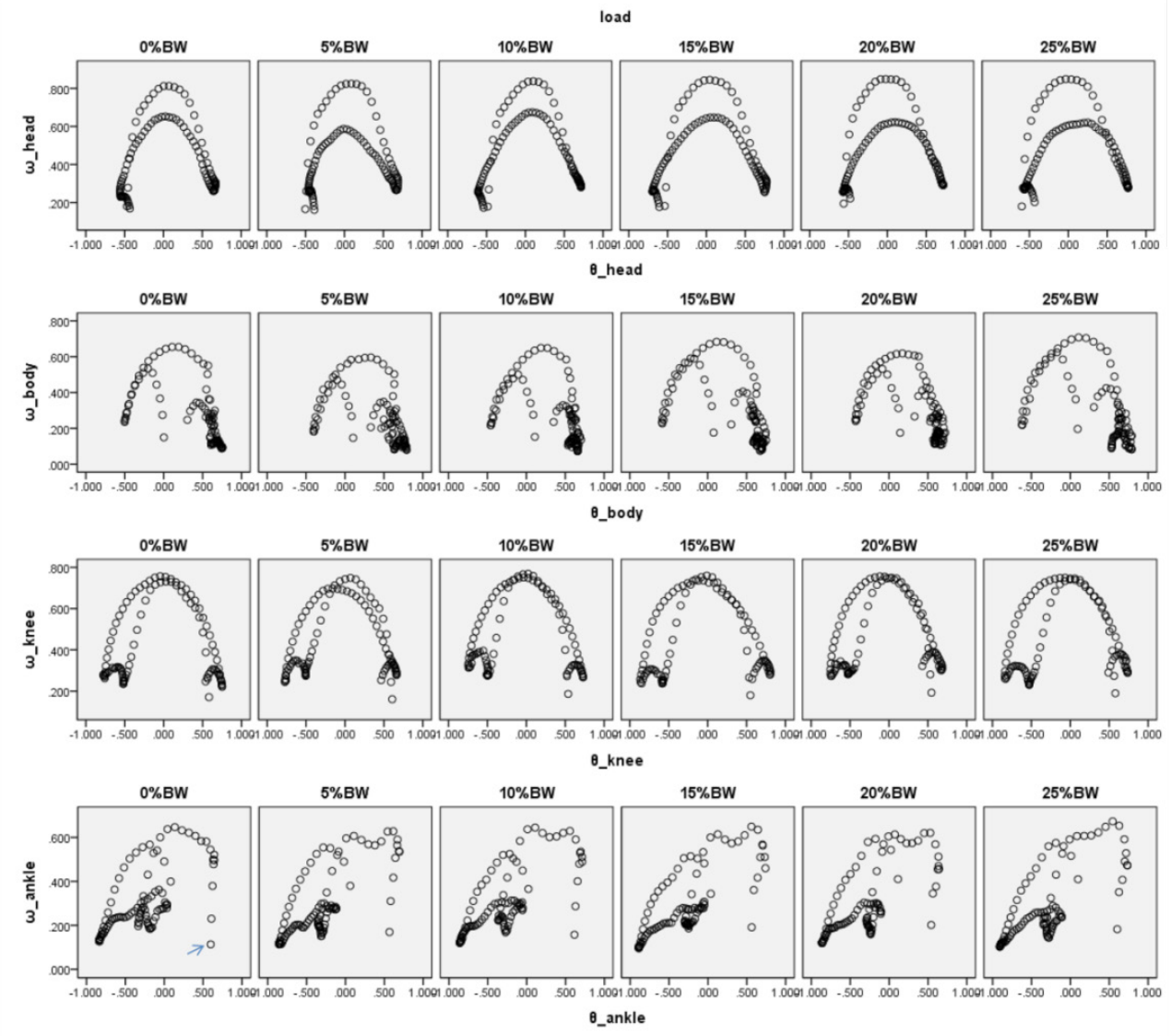

Figure 4. The relationship between the angle and velocity of the head, body, knees and ankles in the six load conditions

From Figure 4, relationships between the angle of joints and velocity were determined as the load increased. Similar track patterns were found from the load of $0 \% \mathrm{BW}$ to $25 \% \mathrm{BW}$; while their standard deviations in terms of $\theta$ and $\omega$ in the head, body, knees and ankles were close within the six load conditions. (SD ranged 0.290.36 degrees for $\theta$-ankle, $0.47-0.54$ degrees for $\theta$-body, 0.46-0.51 degrees for $\theta$-head, 0.35-0.43 degrees for $\theta$-knee; SD ranged $0.18-0.20 \mathrm{arc} / \mathrm{s}$ for $\omega$-ankle, $0.22-0.25 \mathrm{arc} / \mathrm{s}$ for $\omega$-body, $0.23-0.24$ $\mathrm{arc} / \mathrm{s}$ for $\omega$-head, $0.22-0.25 \mathrm{arc} / \mathrm{s}$ for $\omega$-knee).

\section{Phase Angle Across the Walking Cycle}

In terms of the PA of the head, it is located in the neutral position in the initial contact 
with the ground. Further, the PA of the head increased while the body pivoted with the heel. Then it became stable during the stance phase. After that, it moved backwards as the body again led the head in the swing phase. As the load increased, there were no significant differences were found in the PA of the head. Its $S D$ was distributed in a narrow range of 39.240.2 degrees (Figure 5). The PA of the body remained stable between gait cycles of 31-99\%; it fluctuated during heel contact and flattening of the foot. The SD of the PA of the body was between 24.3 and 26.2 degrees, in which 0\%BW was 26.3 degrees and $25 \% \mathrm{BW}$ was 24.3 degrees. A similar tendency was also recorded in the ankle: with the load increasing, the PA in the whole stance phase became stable, while its SD decreased as well (32.0 degrees for 25\%BW, 35.8 degrees for $0 \% \mathrm{BW})$. In the lower limbs, as the knee quickly extended after heel contact, the PA of the knee decreased dramatically around $10 \% \mathrm{GC}$. Then it kept stable for the whole stance phase. In the toe lift, it again fluctuated and its PA increased significantly.
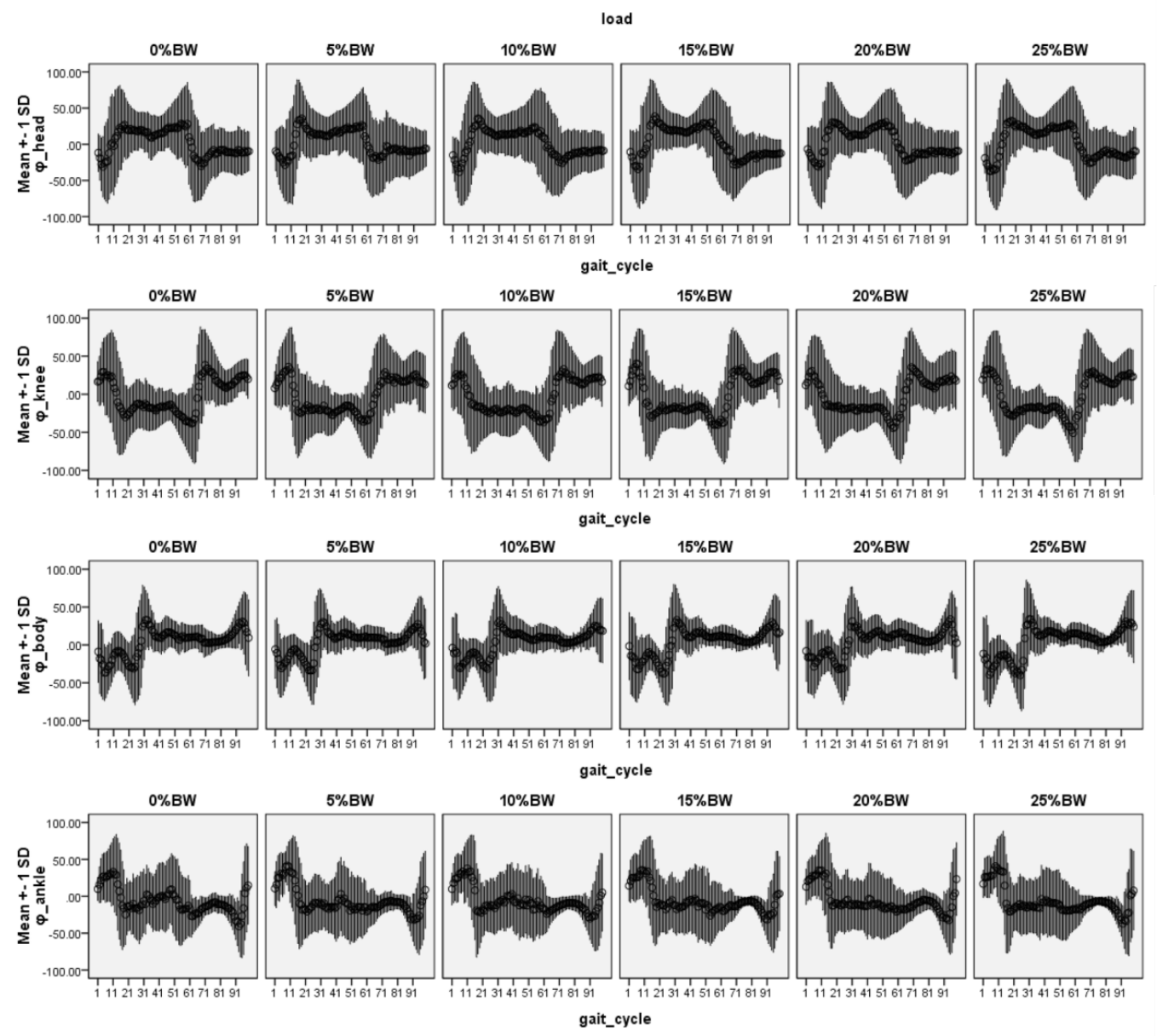

Figure 5. Phase angles of the head, body, knees and ankles in the six load conditions

\section{Relative Phase Angles between Two Joints}

In the $0 \% \mathrm{BW}$ condition, the CRP of the head-body was about 30 degrees in the initial contact, and increased to around 80 degrees when the heel contact finished (Figure 6); then it gradually fell until $35 \% \mathrm{GC}$ and then raised back and peaked at the toe lift. In the swing phase, it fluctuated between the 30 and 60 degrees.
Significant effects of load on the CRP of head and body were found $(p=0.005<0.01)$, where $0 \%$ BW $\quad(p=0.002<0.05), 5 \%$ BW $\quad(p=0.001<0.05)$ and $10 \% \mathrm{BW}(\mathrm{p}=0.008<0.05)$ were recorded with a smaller CRP value than that of $20 \% \mathrm{BW}$.

There were vibrations during the entire gait cycle, but it remained stable with a slightly increasing tendency while supporting the body weight (21-51\% gait cycle). The tendency of 

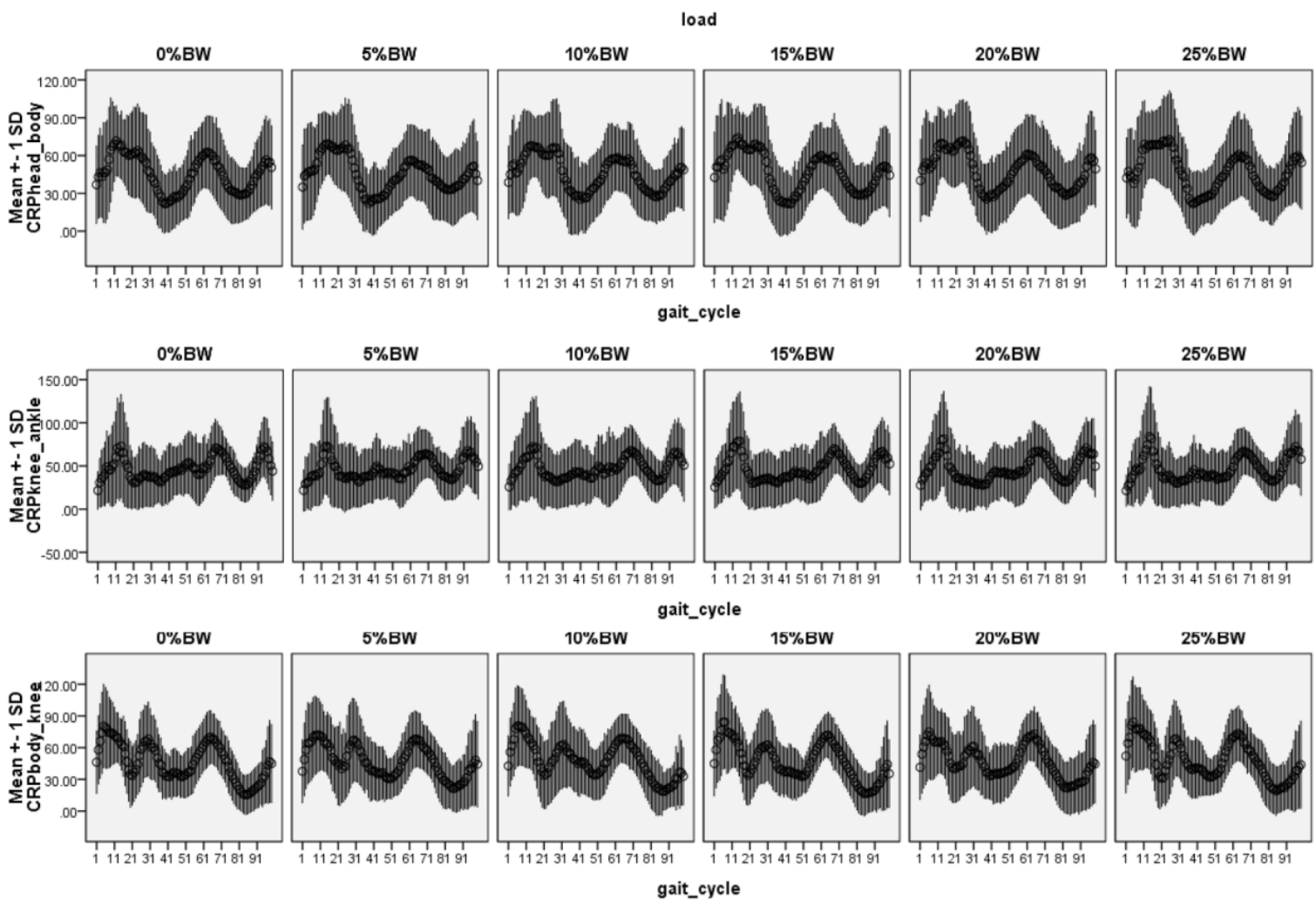

Figure 6. The relative phase angle of head-body, body-knee and knee-ankle while walking

increase was attenuated as the load increased, experiencing three peak values while walking. However, significant influences were not found for the CRP of body-knee ( $p=0.069>0.05)$ and knee-ankle $(p=0.727>0.05)$.

\section{DISCUSSION}

The backpacks covered an area from the neck to the sacrum and directly affected the center of body (COB). When the backpack was loaded, the COB shifted backward. Hence, backwards moments were generated and changed the posture of the upper body. In order to overcome this deficit, a forward tilt of the body and head was usually observed. Hong et al. showed that an increasing backpack load increased the front rake angle of body significantly, especially the comparison between $15-20 \% \mathrm{BW}$ and $0-10 \% \mathrm{BW}$ [10]. The load changed the posture of the body and affected motion and balance. Meanwhile, Pascoe et al. indicated there was a significant difference in forerake angle of body when comparing the $17 \% \mathrm{BW}$ backpack loading with 0\%BW [11].

Our outcomes were consistent with the above literature; significant effect loading on the CRP of head and body was found $(p=0.005<0.01)$, where, $0 \%$ BW $\quad(p=0.002<0.05), \quad 5 \% B W$ $(p=0.001<0.05)$ and 10\%BW $(p=0.008<0.05)$ were recorded with smaller CRP values than those of $20 \% \mathrm{BW}$. This higher CRP indicated a large relative motion between the two joints. So with the additional load, the body tilt increased. However, no significant distinctions were found between $20 \% \mathrm{BW}$ and $25 \% \mathrm{BW}$; we assumed that young schoolchildren aged between 7 and 12 can quickly adapt to a gait with an increased backpack load.

In terms of PA, although significant differences were not found for all PA variables, their SD showed that with the weight of backpack increasing, the SD decreased simultaneously, particularly in the body and ankle. This 
phenomenon implied the load diminished the vibration while walking and made the gait more stable to some extent. This could also be observed by the greater influence of the body and ankle in the stance and swing phase.

In this study, limitations existed and they need to be declared before understanding our findings: (1) children chose their preferred walking speed during measurement; although the walking speed affected the amplitude of motion, in this study, normalization was made to diminish the influence of speed; (2) markers were set on tight clothing rather than skin, which would cause movement of the marker while walking; in order to overcome these defects, a $6 \mathrm{~Hz}$ cut off strategy was applied in the period of data processing.

\section{CONCLUSION}

Coordination in motion of schoolchildren was partially influenced by an increasing load of the backpack, as significant body tilt was performed by the children to overcome the backwards drag, while other body parts were not affected.

\section{REFERENCES}

1.Trevelyan, F.C., Legg, S.J., Back pain in school children-Where to from here, Appl Ergon, 2006, 37, 1, 45-54, https://doi.org/10.1016/j. apergo.2004.02.008.

2.Singh, T., Koh, M., Effects of backpack load position on spatiotemporal parameters and trunk forward lean, Gait Posture, 2008, 29, 1, 49-53, https://doi.org/10.1016/j. gaitpost.2008.06.006.

3.Pau, M., Corona, F., Leban, B. et al., Effects of backpack carriage on foot-ground relationship in children during upright stance,
Gait Posture, 2011, 33, 2, 195-9, https://doi. org/10.1016/j.gaitpost.2010.10.096.

4.Clark, J.E., Phillips, S.J., The development of intralimb coordination in the first six months of walking, Adv Phys, 1991, 81, 245-257.

5.Clark, J.E., Phillips, S.J., A longitudinal study of intralimb coordination in the first year of independent walking: a dynamical systems analysis, Child Dev, 1993, 64, 64, 1143-57, https://doi.org/10.2307/1131331.

6.Clark, J.E., Truly, T.L., Phillips, S.J., A Dynamical Systems Approach to Understanding the Development of Lower Limb Coordination in Locomotion, Sensory-Motor Organizations and Development in Infancy and Early Childhood, 1990, 363-378, https://doi. org/10.1007/978-94-009-2071-2_29.

7.Miller, R.H., Baird, C.J.L., Emmerik, R.E.A.V.et al., Variability in kinematic coupling assessed by vector coding and continuous relative phase, J Biomech, 2010, 43, 13, 2554-2560, https:// doi.org/10.1016/j.jbiomech.2010.05.014.

8.Chiu, S.L., Chou, L.S., Effect of walking speed on inter-joint coordination differs between young and elderly adults, J Biomech, 2012, 45, 2, 275-80, https://doi.org/10.1016/j. jbiomech.2011.10.028.

9. Group of China Obesity Task Force, Body mass index reference norm for screening overweight and obesity in Chinese children and adolescents, Chin J Epidemiology, 2004, 25, 2, 97-102.

10.Hong, Y., Brueggemann, G.P., Changes in gait patterns in 10-year-old boys with increasing loads when walking on a treadmill, Gait Posture, 2000, 11, 3, 254-9, https://doi. org/10.1016/S0966-6362(00)00055-2. 
11.Pascoe, D.D., Pascoe, D.E., Wang, Y.T. (C) 2018 by the author(s). Published by INCDTPet al., Influence of carrying book bags on gait cycle and posture of youths, Ergonomics, 1997, 40, 6, 631-41, https://doi. org/10.1080/001401397187928. ICPI, Bucharest, RO. This is an open access article distributed under the terms and conditions of the Creative Commons Attribution license (http:// creativecommons.org/licenses/by/4.0/). 